\title{
Immunological Profile of Periapical and Periodontal Lesions: Current Concepts in the Role of T Cells
}

\author{
${ }^{1}$ Deepavalli Arumuga Nainar, ${ }^{2}$ Swarna Alamelu, ${ }^{3} \mathrm{KV}$ Arun, ${ }^{4}$ Meenakshisundaram Rajasekaran
}

\begin{abstract}
Periapical lesions of endodontic origin and periodontitis are the two common chronic conditions that constitute the immunoinflammatory responses to putative oral pathogens. Both the conditions encompass similar patterns of development and pathologic mechanisms of host-mediated tissue destruction and subsequent establishment of the lesion. This host inflammatory response is attributed to a large array of immune cells that play a regulatory role in the protective and destructive pathways culminating in these two diseases. Hence, knowledge of the host response involved in their pathogenesis is essential to comprehend the disease process and thus aid in establishing proper therapeutic strategies to keep the host response under control. This review will focus on the pivotal role played by the T cells and its various subsets, namely the T helper (Th)1, Th2, Th17, Treg, Th22, and Th9, and elicit deeper insights on the Th1/Th2 and the Th17/Treg paradigm.
\end{abstract}

Keywords: Periapical lesion, Periodontal lesion, Th subsets, Th1/Th2, Th17/Treg, Th9, Th22.

How to cite this article: Nainar DA, Alamelu S, Arun KV, Rajasekaran M. Immunological Profile of Periapical and Periodontal Lesions: Current Concepts in the Role of T Cells. J Oper Dent Endod 2016;1(2):70-75.

Source of support: Nil

Conflict of interest: None

\section{INTRODUCTION}

The oral cavity is abounded with surface-associated microbial communities - the biofilms which are critical to triggering oral inflammatory diseases, such as periapical and periodontal lesions. ${ }^{1}$ However, pathogens unaided are not adequate to initiate disease. The host protective responses against the bacterial challenge result in local inflammation with destruction and histopathological variations of soft and hard tissues, eventually resulting

\footnotetext{
${ }^{1}$ Senior Lecturer, ${ }^{2}$ Reader, ${ }^{3,4}$ Professor

${ }^{1-3}$ Department of Periodontics, Ragas Dental College and Hospital, Chennai, Tamil Nadu, India

${ }^{4}$ Department of Conservative Dentistry and Endodontics Ragas Dental College and Hospital, Chennai, Tamil Nadu India

Corresponding Author: Meenakshisundaram Rajasekaran Professor, Department of Conservative Dentistry and Endodontics, Ragas Dental College and Hospital, Chennai Tamil Nadu, India, e-mail: endoraja@yahoo.com
}

in endodontic lesions and periodontitis. In addition, various risk factors, if present, may make the host more vulnerable and thus determine the rate of progression of such lesions. ${ }^{2,3}$ Their etiopathogenesis has been widely explored and the role of numerous cell types, especially the immune cells and its pathways, has been well described. ${ }^{4}$ However, the pattern of the adaptive immune responses, especially of the $\mathrm{T}$ cells in the disease progression, needs to be thoroughly understood.

\section{RESEMBLANCES AND PECULIARITIES IN THE ETIOPATHOGENESIS OF PERIAPICAL AND PERIODONTAL LESIONS}

Oral inflammatory diseases usually arise from microbial challenge, which primarily initiates the innate immune response involving the migration of leukocytes and production of proinflammatory cytokines. Eventually, adaptive immune response becomes activated, which involves the T and B cells. Periapical lesions are initiated due to exposure of the dental pulp to oral bacteria, whose antigens provoke both specific and nonspecific immune response and the inflammation, i.e., set in as a consequence results in pulpal necrosis. ${ }^{5}$ It eventually involves the periapical tissue, thus causing the periapical lesion. The initial changes in the periapical region, such as hyperemia can gradually lead to formation of granulation tissue, the periapical granuloma with numerous fibroblasts, vessel, and inflammatory cells. ${ }^{6}$ The granuloma can either remain dormant or can shift to form the periapical cyst with an epithelial-lined cavity. All these pathological changes are thought to be related to the egress of microbes and microbial products from the infected pulp into the periapical region. ${ }^{3}$ Similarly, periodontal disease is a chronic immune inflammatory lesion characterized by the destruction of the tooth-supporting structures, initiated by the periodontal pathogens and progressing due to the overstated host immune response to these antigens. ${ }^{7}$ Thus, inflammatory cell infiltration into the diseased tissue is a characteristic feature of most of the chronic inflammatory lesions including periapical and periodontal disease. Moreover, the balance between the pro- and anti-inflammatory immune mediators governs the consequence of the bone destructive lesions, such as periapical $^{8}$ and periodontal ${ }^{9}$ diseases. 
Immunological Profile of Periapical and Periodontal Lesions: Current Concepts in the Role of T Cells

\begin{tabular}{|c|c|c|c|c|c|c|}
\hline$T h$ & Th1 & Th2 & Th17 & Treg & Th22 & Th9 \\
\hline $\begin{array}{l}\text { Inducing } \\
\text { cytokines }\end{array}$ & $\begin{array}{l}\text { IFN- } \gamma, \text { IFN- } \alpha, \\
\text { IL-12, IL-18, IL-27 }\end{array}$ & IL-4 & $\begin{array}{l}\text { TGF- } \beta / \text { /LL- } 6, \\
\text { TGF- } \beta / I L-21\end{array}$ & TGF- $\beta$ & $\begin{array}{l}\text { TNF- } \alpha \\
\text { IL-6 }\end{array}$ & $\begin{array}{l}\text { IL-4 } \\
\text { TGF- } \beta\end{array}$ \\
\hline $\begin{array}{l}\text { Transcription } \\
\text { factor }\end{array}$ & $\begin{array}{l}\text { STAT-4, STAT-1, } \\
\text { T-bet }\end{array}$ & $\begin{array}{l}\text { STAT-6, STAT-5, } \\
\text { GATA-3 }\end{array}$ & $\begin{array}{l}\text { STAT-3, } \\
\text { ROR- } \gamma \mathrm{t}\end{array}$ & $\begin{array}{l}\text { Foxp3 } \\
\text { STAT-5 }\end{array}$ & $\begin{array}{l}\text { AHR } \\
\text { STAT-3 }\end{array}$ & - \\
\hline $\begin{array}{l}\text { Effector } \\
\text { cytokines }\end{array}$ & $\mathrm{IFN}-\gamma$ & $\begin{array}{l}\text { IL-4, IL-5, IL-10, } \\
\text { IL-13 }\end{array}$ & $\begin{array}{l}\text { IL-17, IL-22, } \\
\text { TNF- } \alpha, \text { IL-21 }\end{array}$ & TGF- $\beta$, IL-10 & IL-22 & IL-9 \\
\hline $\begin{array}{l}\text { Inhibitory } \\
\text { cytokines }\end{array}$ & IL-4 & IL-2, IFN- $\gamma$ & $\begin{array}{l}\text { IL-4, IL-27, } \\
\text { IFN- } \gamma\end{array}$ & IL-1, IL-6 & $?$ & $\begin{array}{l}\text { IL-27, } \\
\text { IFN- } \gamma\end{array}$ \\
\hline Function & $\begin{array}{l}\text { Cell-mediated immunity } \\
\text { against intracellular } \\
\text { pathogens }\end{array}$ & $\begin{array}{l}\text { Humoral immunity } \\
\text { against parasitic and } \\
\text { helminthic infections }\end{array}$ & $\begin{array}{l}\text { Autoimmunity, } \\
\text { cell-mediated } \\
\text { immunity }\end{array}$ & $\begin{array}{l}\text { Immune response } \\
\text { regulation and } \\
\text { suppression }\end{array}$ & $\begin{array}{l}\text { Dermal homeostasis } \\
\text { and in disease, } \\
\text { rheumatoid arthritis }\end{array}$ & $\begin{array}{l}\text { Parasitic } \\
\text { infection? }\end{array}$ \\
\hline
\end{tabular}

AHR, aryl hydrocarbon receptor; Foxp3, Forkhead transcription factor; ROR- $\gamma$ t, retinoic acid-orphan receptor; T-bet, T box expressed in T cell

\section{TH SUBSETS AND THEIR SIGNATURE CYTOKINES IN PERIAPICAL AND PERIODONTAL LESIONS}

Among the infiltrating inflammatory cells, the polymorphonuclear leukocytes are the first line of defense, which later stimulate the migration of lymphocytes and monocytes. Finally, the chronic inflammatory courses are characterized by the presence of inflammatory cell infiltrates comprising the antigen presenting cells and the $\mathrm{T}$ and the $\mathrm{B}$ lymphocytes. The naive $\mathrm{T}$ cells on stimulation get differentiated into CD4+ Thelper cell, CD8+ cytotoxic $\mathrm{T}$ cell, or the $\mathrm{T}$ regulatory cell. The $\mathrm{T}$ helper cells activate both the cellular and the humoral immune responses and thus have received significant attention in the periapical and periodontal literature. Table 1 and Figure 1 summarize the various $\mathrm{T}$ helper (Th) subsets, their inducing and signature cytokines, and transcription factors mediating the signaling pathways.

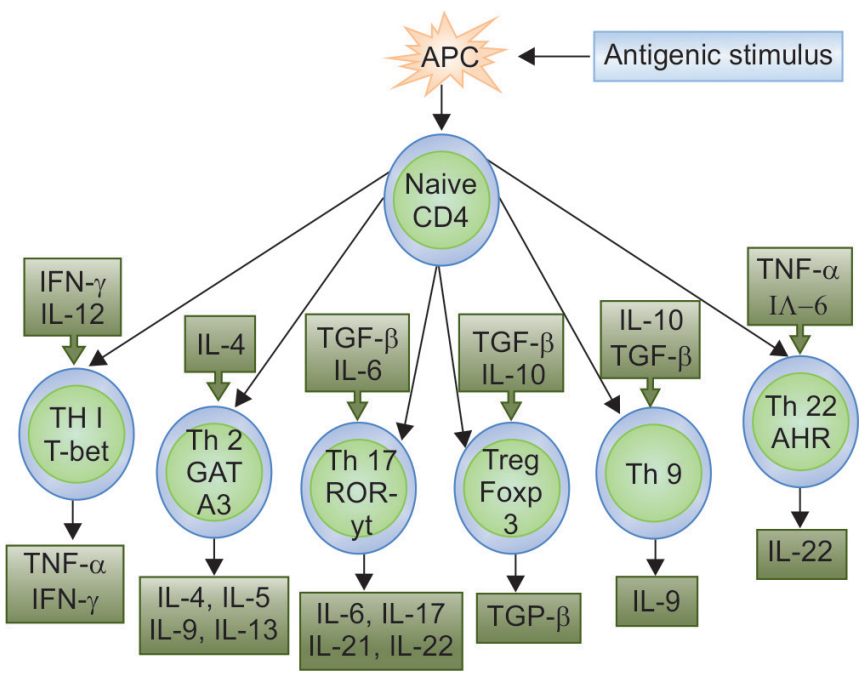

Fig. 1: Diagrammatic representation of the differentiation pattern of various Th subsets

\section{TH1 AND TH2 SUBSETS AND ASSOCIATED/ SIGNATURE CYTOKINES}

The antigen presenting cells, especially the mature dendritic cells expressing costimulatory molecules, produce distinct prototypical cytokine patterns that are critical for the differentiation/polarization of $\mathrm{T}$ helper cells into its subsets, ${ }^{10}$ namely the Th1, Th2, Th17, T regulatory, Th9, and Th22, with subsequent production of characteristic cytokines. ${ }^{11}$ The naive CD4+ T helper cells on activation get differentiated into either Th1 or Th2 subsets based on their functions and a distinct effector cytokine profile. ${ }^{12}$ The Th1 immune response which is responsible for defense against intracellular pathogens and delayed type hypersensitivity is typically cellular and proinflammatory mediated by cytokines IL-1, IL-6, and tumor necrosis factor (TNF)- $\alpha$ along with interferon (IFN)- $\gamma$. The IFN- $\gamma$ along with IL-12 activates the signal transducer and activator of transcription (STAT)- 1 in the naive CD4 T cell, which in turn upregulates T-bet, the master regulator of Th1 differentiation. The IL-12 also activates the STAT- 4 which in turn upregulates IFN- $\gamma$ production by the Th1 cells. Hence, increased expression of IFN- $\gamma$ is the characteristic feature of effector function of Th1 cells leading to progression of periapical and periodontal lesions with ensuing hard tissue destruction. ${ }^{13}$ The Th2 immune response on the other hand is humoral and anti-inflammatory providing defense against extracellular pathogens, such as parasites and helminthes. It is mediated by Th2 cytokines IL-4, IL-5, IL-10, and IL-13 and transforming growth factor $\beta$ (TGF- $\beta$ ), which is responsible for limiting the inflammatory mechanisms and aids the healing processes. The IL-4 produced by the naive CD4 T cells, macrophages, and other cells activates the STAT- 6 which in turn upregulates the GATA-3, the master regulator of Th2 differentiation. ${ }^{14}$ However, in the periodontal literature, the Th1 subset was initially 
thought to be associated with the stable lesion and the Th2 with the progressive ones. ${ }^{7}$ Later, various studies proved that in the active lesions, there was predominance of Th1 cells and reduced expression of Th2 cells. There is ample evidence suggesting that the Th1 and hence, IFN- $\gamma$ are found in higher levels in progressive periapical ${ }^{15}$ and periodontal ${ }^{16}$ lesions. However, the Th1/Th2 archetype which was initially suggested was found to be insufficient to describe the complex etiopathogenesis of periapical and periodontal disease.

\section{TH17 AND TREG SUBSETS AND ITS ASSOCIATED CYTOKINES}

The search to address the inadequacies of the Th1/Th2 paradigm led to the identification of the other subsets, viz., the Th17 and T regulatory subsets and its implication in the periapical and periodontal disease pathogenesis. The Th17 cells produce its signature cytokine repertoire of IL-17A-F, IL-22, and IL-21. ${ }^{17}$ The presence of TGF- $\beta$ along with IL-6/IL-1 or IL-21 in the inflammatory milieu is required for the development of Th17 ${ }^{18,19}$ and IL-23 for the expansion of the subset. ${ }^{20}$ The TGF- $\beta$ induces STAT-3 which in turn activates the retinoid-related orphan receptor (ROR)- $\gamma$ t that is responsible for the expression of its signature cytokines. ${ }^{21}$ Interleukin 17 exerts a destructive response in periodontal disease by receptor activator of nuclear factor kappa-B ligand-mediated osteoclastogenesis, thus resulting in bone resorption. ${ }^{17}$ Studies also showed increased expression of IL-17 messenger ribonucleic acid and IL-17 cells in periodontal disease sites compared with the healthy sites suggestive of possible destructive role for IL-17. ${ }^{22}$ In a similar fashion, the levels of IL-17 and fraction of inflammatory infiltrate are shown to be considerably higher in symptomatic lesions of periapical disease. Thus, it suggests that IL-17 may exacerbate inflammation in chronic periapical lesions. ${ }^{23}$ However, it was also shown that under experimental conditions, the IL-17 may exert a protective role as there was Porphyromonas gingivalis-induced periodontal bone loss after genetic deletion of IL-17 receptors. ${ }^{24}$ It was also demonstrated that by suppressing the chronic inflammatory cell infiltration, IL-17 receptor A signaling was protective in infection-induced mouse periapical bone destruction. ${ }^{25}$ These evidences suggest that it is known to exert a biphasic response in relation to its effects on alveolar bone destruction.

The T regulatory cells on the other hand were identified as a separate subset by Gershon, ${ }^{26}$ where the naive $T$ cells differentiated into regulatory cells in the presence of TGF- $\beta$ only and devoid of IL- $6 / \mathrm{IL}-1 .{ }^{27}$ FoxP3 is the key transcription factor required for $\mathrm{T}$ reg differentiation and function. ${ }^{28}$ Mediated by TGF- $\beta$, T reg cells elicit immunosuppressive/immunoregulatory effects by secretion of IL-10 and TGF- $\beta .^{29}$ They are known to control the immune response through a suppressive effect on osteoclast differentiation and bone resorption. ${ }^{30}$ Thus, by inducing the secretion of IL-10, T reg cells are known to regulate inflammation in periapical lesions. ${ }^{31}$ Similarly, in the periodontal tissue, the T reg subset is shown to be associated with increased secretion of TGF- $\beta$, IL-10, and an inhibitory molecule, CTLA-4, hence proving to be protective and suppressive in the disease progression. ${ }^{32}$

Hence, research led to the interesting fact that the progression and outcome of both the periapical and periodontal lesions were found to be influenced by the Th17/Treg archetype.

\section{THE NEWER TH9 AND TH22 SUBSETS}

However, more complex cytokine networks were implicated in periapical lesion evolvement. Various studies on human and experimental periapical lesions showed that the Th9 and Th22 cytokines were also contributing to its pathogenesis, nevertheless on the lesion stability. ${ }^{33}$ The lineage-specific cytokines of the Th9 and Th22 subsets are IL-9 and IL-22 respectively. These cytokines are biphasic in nature, which indicates the fact that their protective and destructive properties may fluctuate considerably depending on the surrounding inflammatory milieu. The intracellular signaling pathways are not fully illustrated; however, the Th22 differentiation is known to be stimulated by the aryl hydrocarbon (AHR) and RORC when mediated by TNF- $\alpha$ and IL- $6 .{ }^{34}$ Araujo-Pires et al simultaneously analyzed the differential expression of various Th subsets in human periapical lesions and demonstrated that cytokines exhibit as clusters accounting for the lesion activity-inactivity status. The study demonstrated the association of IFN- $\gamma$, TNF- $\alpha$, IL-17, and IL-21 with lesion activity and association of IL-4, IL-9, IL-10, IL-22, and FOXP3 with lesion inactivity. ${ }^{35}$ Similarly, another study has shown the association of IL-9 and IL-22 in inactive human and animal periapical lesions. ${ }^{33}$ These studies suggest the contribution of Th-9 and Th-22 pathways in periapical lesion stability.

Although the role of IL-22 has been identified in the dermal lesions, its role in periodontal lesions is not fully elucidated. However, as IL-22 in localized in the gingival epithelium and is known to induce secretion of antimicrobial peptides, namely defensins, ${ }^{36}$ it may be assumed that they have a role in the innate immune mechanisms of the periodontium. Kato-Kogoe et al found the expression of IL-22 receptors in the periodontal tissues. It has also been shown that IL-22 leads to mineralized nodule formation and induction of bone-forming gene expression in periodontal ligament (PDL) cells. It was thus concluded 
that IL-22 has the potential to augment the mineralized matrix-forming ability of PDL cells. ${ }^{37}$

The Th- 9 cells when exposed to TGF- $\beta$ and IL-4 results in secretion of IL-9, ${ }^{38}$ which is known to influence the expression of proinflammatory cytokines, such as TNF- $\alpha$, IFN- $\gamma$, IL-1, and IL-17. ${ }^{39}$ However, its exact role in periodontal disease progression needs to be fully understood.

\section{PERIAPICAL AND PERIODONTAL LESIONS - THEIR ENIGMATIC DISTINCTIVENESS}

The oral putative pathogens, under favorable conditions, can initiate formation of dental caries and dental plaque, eventually leading to periapical lesions and periodontal disease if uninterrupted at the early stages. The etiopathogenesis of these lesions has been widely studied over the last few decades.

Both periapical and periodontal lesions exhibit a paradoxical condition in which the same host immune response that provides protection against the microbial communities and its products also results in destruction of the host tissue. Hence, stimulation of these systems, in view of delivering defense, almost always results in some amount of host tissue destruction and if allowed to continue, ends in tooth loss.

Nevertheless, with the continual identification of newer Th subsets and their role in the lesion development, the conception of their pathogenesis becomes more complicated. Treatment modalities to combat such destructive host response also requires a thorough understanding of the disease process in terms of involvement of the Th subset's differentiation, subsequent activation, and the role of their signature cytokines in the effector functions.

\section{PARADIGM SHIFT FROM THE TH1/TH2 TO THE TH17/T REG RECIPROCITY}

For almost two decades, the Th1/Th2 dichotomy presented a dynamic conceptual structure for investigating and understanding the etiopathogenesis of chronic inflammatory diseases including the periapical and periodontal diseases. The Th1/Th2 lineage is merely antagonistic and reciprocating, that IFN- $\gamma$ and IL-4 antagonize each other at both molecular and cellular levels. However, this bifurcation could not completely explain the other specialized functions of the Th cells, especially those mediated by the extracellular pathogens, the eradication of which depends on the efficient orchestration of inflammatory infiltrates and class switching of the B cells to immunoglobulin $\mathrm{G}$ antibodies for opsonization of microbes. ${ }^{40}$ Besides, it could not sufficiently explain the outcomes of T-cell-mediated immune diseases. Many of the cytokines produced also could not fit into either of the subsets. Nearly all the inflammatory diseases were categorized into one or the other subset regardless of how disordered they fit into this archetype. It was until the discovery of the Th-17 that this discrepancy in the functional repertoire of the $\mathrm{CD} 4 \mathrm{~T}$ cells were complete. ${ }^{41}$ Th-17 cells produce IL-17 family of cytokines, IL-17A and IL-17F, targeting innate immune cells, granulocytecolony stimulating factor (G-CSF) and IL-8 for inducing neutrophil production and recruitment, granulocyte macrophage CSF for promoting enhanced production of monocytes and granulocytes. ${ }^{42}$ Interleukin 17 primarily binds to IL-17 RA and initiates signaling of proinflammatory response, strongly associated with progression of several autoimmune and inflammatory disorders, such as systemic lupus erythematosus, rheumatoid arthrosis, etc. Thus, there is ample evidence to suggest that Th-17 is a committed osteoclastogenic subset linking Th cell stimulation to bone loss in inflammatory conditions. ${ }^{43}$ Besides, Th-17 also produces IL-22, which enhances antibacterial defense and integrity of the epithelial barrier. ${ }^{44}$

Adding to the significance, TGF- $\beta$ played a key role in the de novo generation of yet another subset of Th cells, namely the FOXP3+ regulatory T cells. ${ }^{29}$ The STAT-3 expressing $\mathrm{T}$ reg cells are critical to suppress Th-17 stimulation. These cells, in response to IFN- $\gamma$ and IL-4, upregulate T-bet and IRF4 (IFN regulatory Factor 4), thus control the effector $\mathrm{T}$ cells that release proinflammatory cytokines. ${ }^{45}$ Sakaguchi et al ${ }^{46}$ have shown that these cells also coexpress CD25, which was key to control autoreactive $\mathrm{T}$ cells and for immune regulation to infection. Alshwaimi et $\mathrm{al}^{47}$ in their study in a mouse periapical lesion showed that $\mathrm{T}$ reg cells are analogous to periapical bone loss, suggesting its role in lesion stabilization. Human studies have eventually shown that $\mathrm{T}$ reg cells being a potential source for IL-10 secretion can regulate lesion development. ${ }^{48}$ Similarly, in mouse periodontitis models, these cells are expressed in high numbers, suggesting its suppressive role in periodontal lesions as well. This hypothesis was proved later in human studies that $T$ reg cells restrain the periodontal tissue destruction as they are associated with secretion of TGF- $\beta$ and IL-10. ${ }^{49}$

Hence, there is abundant evidence to suggest that close functional connotation of these cells occurs at all stages of periapical and periodontal lesion development and that the Th-17/T reg act as effector and suppressor respectively.

Thus, their relationship proves that there exists not just a functional antagonism, but a true paradigm in their generation too. ${ }^{50}$ Hence, the balance between $\mathrm{T}$ reg and Th17 proves important for homeostasis and when an imbalance occurs, there is dysregulation in the host immune system leading to progression of periapical and periodontal disease. ${ }^{51}$ 


\section{CONCLUSION}

Oral inflammatory disease activity is determined by a complex interplay between the immune system and the microbial communities. The revisiting of existing periapical and periodontal literature with further studies enlightening the new discoveries of the emerging Th subsets may help clarify how the inflammatory response results in destruction of the pulpal and periodontal tissue, while mostly waning to control the oral pathogens. This knowledge is indispensible for the innovation of immunemodulatory intervention strategies to target the various Th pathways for refinement of the host response with the view of increasing its protective aspect while reducing its destructive capability. Hence, further extensive studies are required to elucidate the complex role of Th cellular immune response and their associated cytokines in the modulation of immunoinflammatory response.

\section{REFERENCES}

1. Beikler T, Flemming TF. Oral biofilm-associated diseases: Trends and implications for quality of life, systemic health and expenditures. Periodontol 20002011 Feb;55(1):87-103.

2. Graves DT. Cytokines that promote periodontal tissue destruction. J Periodontol 2008 Aug;79(Suppl 8):1585-1591.

3. Nair PNR. Apical periodontitis: a dynamic encounter between root canal infection and host response. Periodontol 20001997 Feb;13(1):121-148.

4. Graves DT, Oates T, Garlet GP. Review of osteoimmunology and the host response in endodontic and periodontal lesions. J Oral Microbiol 2011 Jan 17;3(suppl).

5. Stashenko P, Teles R, De Souza R. Periapical inflammatory responses and their modulation. Crit Rev Oral Biol Med 1998;9(4):498-521.

6. Piattelli A, Artese L, Rosini S, Quaranta M, Musiani P. Immune cells in periapical granuloma: Morphological and immunohistochemical characterization. J Endod 1991 Jan;17(1):26-29.

7. Gemell E, Yamazak K, Gregory J. The role of T cells in periodontal disease: Homeostasis and autoimmunity. Periodontol 2000 2007;43:14-40.

8. Silva TA, Garlet GP, Fukada SY, Silva JS, Cunha FQ. Chemokines in oral inflammatory diseases: apical periodontitis and periodontal disease. J Dent Res 2007 Apr;86(4): 306-319.

9. Garlet GP. Destructive and protective roles of cytokines in periodontitis: a reappraisal from host defence and tissue destruction viewpoints. J Dent Res 2010 Dec;89(12):1349-1363.

10. Cutler CW, Jotwani R. Antigen-presentation and the role of dendritic cells in periodontitis. Periodontol 2000 2004;35(1):135-157.

11. Murphy KM, Reiner SL. The lineage decisions of helper T cells. Nat Rev Immunol 2002 Dec;2(12):933-944.

12. Jankovic D, Liu Z, Gause WC. Th1 and Th2 cell commitment during infectious disease: asymmetry in divergent pathways. Trends Immunol 2001 Aug;22(8):450-457.

13. Yang J, Murphy TL, Ouyang W, Murphy KM. Induction of interferon-gamma production in Th1 CD4+ T cells: evidence for two distinct pathways for promoter activation. Eur J Immunol 1999 Feb;29(2):548-555.
14. Zheng W, Flavell RA. The transcription factor GATA-3 is necessary and sufficient for Th2 cytokine gene expression in CD4 T cells. Cell 1997 May;89(4):587-596.

15. Kawashima N, Stachenko P. Expression of bone-resorptive and regulatory cytokines in murine periapical inflammation. Arch Oral Biol 1999 Jan;44(1):55-66.

16. Trombone AP, Claudino M, Colavite P, de Assis GF, AvilaCampos MJ, Silva JS, Campanelli AP, Ibanez OM, de Franco M, Garlet GP. Periodontitis and arthritis interaction in mice involves a shared hyper-inflammatory genotype and functional immunological interferences. Genes Immun 2010 Sep;11(6):479-489.

17. Miossec P, Korn T, Kuchroo VK. Interleukin-17 and type 17 helper T cells. N Engl J Med 2009 Aug;361(9):888-898.

18. Ivanov II, McKenzie BS, Zhou L, Tadokoro CE, Lepelley A, Lafaille JJ, Cua DJ, Littman DR. The orphan nuclear receptor RORgammat directs the differentiation program of proinflammatory IL-17+ T helper cells. Cell 2006 Sep;126(6):1121-1133.

19. Yang L, Anderson DE, Baecher-Allan C, Hastings WD, Bettelli E, Oukka M, Kuchroo VK, Hafler DA. IL-21 and TGF-beta are required for differentiation of human TH17 cells. Nature 2008 Jul;454(7202):350-352.

20. Aggarwal S, Ghilardi N, Xie MH, de Sauvage FJ, Gurney AL. Interleukin-23 promotes a distinct $\mathrm{CD} 4 \mathrm{~T}$ cell activation state characterized by the production of interleukin-17. J Biol Chem 2003 Jan;278(3):1910-1914.

21. Chen Z, Laurence A, O'Shea JJ. Signal transduction pathways and transcriptional regulation in the control of Th17 differentiation. Semin Immunol 2007 Dec;19(6):400-408.

22. Cardoso CR, Garlet GP, Crippa GE, Rosa AL, Junior WM, Rossi MA, Silva JS. Evidence of the presence of T helper type 17 cells in chronic lesions of human periodontal disease. Oral Microbiol Immunol 2009 Feb;24(1):1-6.

23. Colic M, Vasilijic S, Gazivoda D, Vucevic D, Marjanovic M, Lukic A. Interleukin-17 plays a role in exacerbation of inflammation within chronic periapical lesions. Eur J Oral Sci 2007 Aug;115(4):315-320.

24. Yu JJ, Ruddy MJ, Wong GC, Sfintescu C, Baker PJ, Smith JB, Evans RT, Gaffen SL. An essential role for IL-17 in preventing pathogen initiated bone destruction: Recruitment of neutrophils to inflamed bone requires IL-17 receptor-dependent signals. Blood 2007 May;109(9):3794-3802.

25. AlShwaimi E, Berggreen E, Furusho H, Rossall JC, Dobeck J, Yoganathan S, Stashenko P, Sasaki H. IL-17 receptor A signaling is protective in infection-stimulated periapical bone destruction. J Immunol 2013 Aug;191(4):1785-1791.

26. Gershon RK, Kondo K. Cell interactions in the induction of tolerance: the role of thymic lymphocytes. Immunology 1970 May;18(5):723-737.

27. Gonzalez Garcia C, Martin Saavedra F, Ballester A, Ballester S. The Th17 lineage: answers to some immunological questions. Immunologia 2009 Jan-Mar;28(1):32-45.

28. Tang Q, Bluestone JA. The Foxp3+ regulatory T cell: a jack of all trades, master of regulation. Nat Immunol 2008 Mar;9(3): 239-244.

29. Chen W, Jin W, Hardegen N, Lei KJ, Li L, Marinos N, McGrady G, Wahl SM. Conversion of peripheral CD4 + CD25- naive $\mathrm{T}$ cells to CD4 + CD25+ regulatory T cells by TGF-beta induction of transcription factor Foxp3. J Exp Med 2003 Dec;198(12): 1875-1886.

30. Zaiss MMR, Axmann J, Zwerina K, Polzer E. Treg cells suppress osteoclast formation: a new link between the 
immune system and bone. Arthritis Rheum 2007 Dec;56(12): 4104-4112.

31. Colic M, Gazivoda D, Vasilijic S, Vucevic D, Lukic A. Production of IL 10 and IL-12 by antigen-presenting cells in periapical lesions. J Oral Pathol Med 2010 Oct;39(9):690-696.

32. Cardoso CR, Garlet GP, Moreira AP, Junior WM, Rossi MA, Silva JS. Characterization of CD4+CD25+ natural regulatory $\mathrm{T}$ cells in the inflammatory infiltrate of human chronic periodontitis. J Leukoc Biol 2008 Jul;84(1):311-318.

33. Aranha AM, Repeke CE, Garlet TP, Vieira AE, Campanelli $\mathrm{AP}$, Trombone AP. Evidence supporting a protective role for th9 and th22 cytokines in human and experimental periapical lesions. J Endod 2013 Jan;39(1):83-87.

34. Yssel H, Pene J. Interleukin-22 producing T cells: a specialized population involved in skin inflammation? Immunol Cell Biol 2009 Sep;87:574-576.

35. Araujo-Pires AC, Francisconi CF, Biguetti CC, Cavalla F, Aranha AM, Letra A, Trombone AP, Faveri M, Silva RM, Garlet GP. Simultaneous analysis of T helper subsets (Th1, Th2, Th9, Th17, Th22, Tfh, Tr1 and Tregs) markers expression in periapical lesions reveals multiple cytokine clusters accountable for lesions activity and inactivity status. J Appl Oral Sci 2014 Jul-Aug;22(4):336-346.

36. Boniface K, Guigouard E, Pedretti N, Garcia M, Delwail A, Bernard FX, Nau F, Guillet G, Dagregorio G, Yssel H, et al. A role for T cell-derived interleukin 22 in psoriatic skin inflammation. Clin Exp Immunol 2007 Dec;150(3):407-415.

37. Kato-Kogoe N, Nishioka T, Kawabe M, Kataoka F, Yamanegi K, Yamada N, Hata M, Yamamoto T, Nakasho K, Urade M, et al. The promotional effect of IL 22 on mineralization activity of periodontal ligament cells. Cytokine 2012 Jul;59(1):41-48.

38. Veldhoen M, Uyttenhove C, van Snick J, Helmby H, Westendorf A, Buer J. Transforming growth factor beta "reprograms" the differentiation of $\mathrm{T}$ helper 2 cells and promotes an interleukin 9-producing subset. Nat Immunol 2008 Dec;9(12):1341-1346.

39. Li H, Rostami A. IL-9: Basic biology, signalling pathways in CD4+ T cells and implications for autoimmunity. J Neuroimmune Pharmacol 2010 Jun;5(2):198-209.
40. Weaver CT, Elson CO, Fouser LA, Kolls JK. The Th17 pathway and inflammatory diseases of the intestines, lungs and skin. Annu Rev Pathol 2013 Jan;8:477-512.

41. Weaver CT, Hatton RD, Mangan PR, Harrington LE. IL-17 family cytokines and the expanding diversity of effector T cell lineages. Annu Rev Immunol 2007;25:821-852.

42. Kolls JK, Linden A. Interleukin-17 family members and inflammation. Immunity 2004 Oct;21(4):467-476.

43. Miossec P, Kolls JK. Targeting IL-17 and TH17 cells in chronic inflammation. Nat Rev Drug Discov 2012 Oct;11(10):763-776.

44. Sonnenberg GF, Fouser LA, Artis D. Border patrol: regulation of immunity, inflammation and tissue homeostasis at barrier surface by IL-22. Nat Immunol 2011 May;12(5):383-390.

45. Zheng Y, Chaudhry A, Kas A, deRoos P, Kim JM, Chu TT, Corcoran L, Treuting P, Klein U, Rudensky AY. Regulatory T-cell suppressor program co-opts transcription factor IRF4 to control T(H)2 responses. Nature 2009;458(7236):351-356.

46. Sakaguchi S, Ono M, Setoguchi R, Yagi H, Hori S, Fehervari Z, Shimizu J, Takahashi T, Nomura T. Foxp3+ CD25+ CD4+ natural regulatory $\mathrm{T}$ cells in dominant self-tolerance and autoimmune disease. Immunol Rev 2006 Aug;212:8-27.

47. Alshwaimi E, Purcell P, Kawai T, Sasaki H, Oukka M, CamposNeto A. Regulatory T cells in mouse periapical lesions. J Endod 2009 Sep;35(9):1229-1233.

48. Menezes R, Garlet TP, Trombone AP, Repeke CE, Letra A, Granjeiro JM. The potential role of suppressors of cytokine signaling in the attenuation of inflammatory reaction and alveolar bone loss associated with apical periodontitis. J Endod 2008 Dec;34(12):1480-1484.

49. Nakajima T, Ueki-Maruyama K, Oda T, Ohsawa Y, Ito H, Seymour GJ, Yamazaki K. Regulatory T-cells infiltrate periodontal disease tissues. J Dent Res 2005 Jul;84(7):639-643.

50. Betteli E, Carrier Y, Gao W, Korn T, Strom TB, Oukka M, Weiner HL, Kuchroo VK. Reciprocal development pathways for the generation of pathogenic effector TH17 and regulatory T cells. Nature 2006 May;441(7090):235-238.

51. Homey B. After TH1/TH2 now comes Treg/TH17: Significance of $\mathrm{T}$ helper cells in immune response organization. Hautarzt 2006 Aug;57(8):730-732. 